\title{
EDITORIAL
}

\section{ABEC Brasil and JATM in the Promotion of Ethics in Scientific Publishing}

\section{Silvia Regina Galleti ${ }^{1}$, Sigmar de Mello Rode²}

\section{$\mathrm{T}$}

he Associação Brasileira de Editores Científicos, ABEC Brasil, is a nationwide and non-profitable civil society. Founded in 1985, it brings together people and companies in an attempt to develop and enhance the publishing of technical and scientific journals; to improve communication and dissemination of information; to keep up with the exchanging of ideas, the debating of issues and the defense of common interests. Since its founding, the ABEC Brasil has always had as a goal to ensure publishing standards of form and content of technical and scientific publications in the country; to keep in touch with and to assist correlated institutions and societies in the country and abroad; to regularly disseminate issues of technical and scientific editorial interest; to promote conferences, seminars and courses on its objectives; to represent the interest of national scientific journals, while always keeping an ethical standard of quality and science. In order to emphasize the role of ABEC Brasil in fulfilling the goals mentioned above, the assistance given to editors for the creation and maintenance of scientific journals is mentioned. That was how the Journal of Aerospace Technology and Management, JATM, was created, in 2009. The group of idealizer creators of this renowned journal on the aerospace field had the initiative of seeking for ABEC Brasil's guidance on the founding of this journal. ABEC Brasil was the one that steered decision making towards the creation of a journal published exclusively in English, intended for the dissemination of research results of both Brazilian and foreign professionals, granting a international character to the publication since its creation. The fact that JATM publishes solely in English is already a facilitator in its internationalization process (Morais et al., 2012). Indexing this journal in recognized data bases will cause this journal to consolidate itself as for its main objective, which is to be internationally recognized as a vehicle of scientific dissemination in the aerospace field. Its editors do never get tired of searching for a larger number of indexes for JATM. Already indexed by SCOPUS, DOAJ, LATINDEX and REDALYC, among others, the JATM currently attempts being indexed by SciELO. The seriousness and professionalism, with which its editorial board conducts its activities, as well as the quality of the works published in the journal, are factors which will promote, undoubtedly, the joining of JATM in this electronic library. Still within ABEC Brasil's objectives, there is the promoting of meeting between its associates and interested parties in general, through courses, workshops and gatherings. These events are intended to provide their audience with knowledge, improvement and debates on what is latest in scientific editorial. The conducting of these events is given, preferably, in association with institutions and/or scientific journals. In order to improve the knowledge of its editors, as well as to maintain JATM aligned with international tendencies, its editors are always present in events promoted by ABEC Brasil. In addition to that, the maturity and professionalism achieved by this journal's editorial board may be demonstrated by the initiative of JATM on promoting in the premises of the Departamento de Ciência e Tecnologia Aeroespacial, DCTA, in São José dos Campos, the XXII Course of Scientific Publishing in association with ABEC Brasil, have taken place on the $15^{\text {th }}$ to the $17^{\text {th }}$ of last May. The organization of this event proved that both ABEC Brasil and JATM are in sync as for the current concerns regarding scientific publishing. The choice of the central theme of this course was unanimous: "Building an ethical publication of international quality". One must 
remember that, the making of an ethical publication depends, fundamentally, on two "actors": the author(s) and the editor. If the work submitted to publication has not been ethically conducted, we will have a loss not only on its dissemination, but also on its reproduction and credibility. We may say science, as a whole, will be at loss. On the other hand, it will have no use to have an ethically conducted and written work if, when submitting it to a journal, one comes across lack of ethics in conducting the editorial committee. The dissemination of quality science must be ethical in all aspects. There must always be integrity in research and ethics in the publication (Rode, 2011). This is an undisputable matter. The ABEC Brasil recognizes the importance of discussing this theme. This is evidenced in the programming of its events, where ethics and plagiarism are recurring themes. National journals must always demonstrate the ethical integrity by which they conduct their works. This will ensure credibility to both authors and readers and, as a result, grant visibility to the journal (Rode and Galleti-Queiroz, 2013). JATM proves that right. Attentive to global trends, it implemented the use of a system to detect plagiarism in papers submitted to publishing. Also, as trying to ensure the ethical evaluation of the works, the JATM instructs its reviewers into providing constructive evaluations. The international projection of a brazilian journal is absolutely possible. It is a matter of professionalism, integrity and having a qualified staff. We lay here the example of JATM: a young, but yet determined, journal, under ethical conduction, seeking for the constant update and improvement of its editorial board.

\section{REFERENCES}

Morais, A. M. F., Moreira, J.P., and Avelar, A. C., 2012, "Journal of Aerospace Technology and Management: conquistas e desafios para internacionalização", Retrieved in September 15th, 2014, from http:// ocs.abecbrasil.org.br/Index.php/WEC/VIIWEC/paper/viewFile/23/17

Rode, S. M., 2011, "Integrity in scientific publication", The Journal of
Venomous Animals and Toxins including Tropical Diseases, Vol. 17, No.1, pp 118.

Rode, S. M. and Galleti-Queiroz, S. R., 2013, "Ethical publication providing social benefit: challenges of editors and the ABEC Brasil", Brazillian Oral Research, Vol. 27, No. 2, pp. 89-90 